\title{
The Move Toward a Cashless Society: A Closer Look at Payment Instrument Economics
}

\author{
DANIEL D. GARCIA-SWARTZ
}

LECG

ROBERT W. HAHN *

American Enterprise Institute-Brookings Joint Center for Regulatory Studies

ANNE LAYNE-FARRAR

LECG

\begin{abstract}
Ever since the first general-purpose charge card debuted in the early 1950s, pundits have been predicting the "cashless society". Over fifty years later, we may finally be getting close to that vision. This study is the first to examine empirically the move toward a cashless society using a cost-benefit framework. We find that when all key parties to a transaction are considered and benefits are added, cash and checks are more costly than many earlier studies suggest. In general, the shift toward a cashless society appears to be a beneficial one.
\end{abstract}

\section{Introduction}

Over the course of history, there have been many different forms of payment systems, including barter, gold, and paper currency. In the mid-twentieth century, charge cards debuted. Ever since then, pundits have been predicting the demise of cash and the emergence of a cashless society. Today, we still pay with cash and checks, but certain payment cards are growing at a much faster rate than paper instruments. In this paper, we analyze the costs and benefits of payment instruments involved in the shift toward a cashless society.

As new payment systems have been introduced, researchers have critically examined their costs from both a private and social perspective. Scholars have studied why

\footnotetext{
* Contact author. AEI-Brookings, 1150 17th St. NW, Washington, DC 20036; E-mail: rhahn@aeibrookings.org. We would like to thank Howard Chang, David Humphrey, Randy Kroszner, Richard Schmalensee, and Joanna Stavins, an anonymous referee and the journal editor, for helpful comments, and Murtaza Akhter, Irina Danilkina, Melissa Long, and Nese Nasif for excellent research assistance. The authors would like to thank the AEI-Brookings Joint Center and Visa U.S.A. for financial support. This paper reflects the views of the authors and not necessarily those of their affiliated institutions.
} 
individuals and firms use or accept various payment instruments. Some have also considered whether economic welfare would be improved if certain payment instruments displaced others, such as if electronic instruments displaced paper-based instruments. Our study is the first to empirically examine the move toward a cashless society using benefits as well as costs.

A deeper understanding of the economics of payment instruments could have important implications for policy. For example, two recent regulatory cases examine whether payment cards are "overused" in a social welfare sense: the investigation of MasterCard by the Office of Fair Trading in the United Kingdom and the Australian central bank investigation of MasterCard and Visa. In brief, the regulators claim that payment card systems charge "unjustifiably high" fees to merchants for payment cards while the banks issuing payment cards provide consumers with below-cost services and loyalty rewards. ${ }^{1}$ By not charging consumers the full marginal cost imposed by their card use, the regulators assert that payment card systems encourage consumers to overuse payment cards, which they can afford to do profitably because merchants shoulder the cost.

In the United States, the scrutiny has been no less intense, but has emphasized different pricing aspects of the payment card systems. In the widely publicized Wal-Mart case, for example, the plaintiffs argued that debit cards were illegally tied to credit cards. Merchants accepting credit cards also had to accept debit cards. Plaintiffs claimed that this tie enabled the payment card systems to charge "exorbitant" fees to merchants, although they did not argue that the end result was debit card overuse.

While all of these policy issues are worth examining, we would argue that most of the empirical studies addressing them have been incomplete because they do not adequately consider key parties in a transaction nor include economic benefits. The main objective of this paper is to illustrate the importance of careful cost-benefit analysis in addressing key policy questions involving payment instruments. The empirical applications we develop illustrate how cost-benefit analysis can provide policy makers with insights on how moves toward a cashless society affect net economic welfare. We find that retailer cost studies suggesting that payment cards are very costly are misleading when used to argue that payment cards are costly for the economy as a whole. When other parties to a transaction are considered and benefits are included, payment cards appear competitive with other forms of payment available to consumers. Our results suggest that the slow but inevitable shift toward a cashless society is beneficial, providing certain groups with clear benefits while not costing more to process in the aggregate than traditional paper transactions.

The paper proceeds as follows. Section II briefly reviews the academic literature. A significant portion of this literature has focused solely on the costs of payment instruments, and thus provides little guidance on the net benefits of substituting one payment instrument for another. Section III presents a simple theoretical framework for assessing the costs and benefits of payment instruments. In Section IV, we present two empirical case studies. ${ }^{2}$ To make the issue tractable, our case studies focus on two retail environments: grocery stores and electronics specialty stores. Section V presents our main conclusions.

\footnotetext{
${ }^{1}$ Merchants pay a fee, referred to as the "merchant discount”, to the banks that process their payment card transactions. Merchants' banks must then pass on a portion of that fee, referred to as the "interchange fee", to cardholders' banks. Thus, merchants indirectly pay card issuing banks for each payment card transaction.

${ }^{2}$ A companion paper, Garcia-Swartz et al. (2006b), includes the full details of these case studies, plus a third case study, on discount store transactions.
} 


\section{$2 \quad$ Literature review}

Several scholars have evaluated the costs of various payment instruments. Most ignore the benefits side of the equation altogether; others do an incomplete job of examining costs. A few look solely at benefits without considering costs.

Humphrey and Berger (1990) present one of the earliest attempts to comprehensively estimate payment instrument costs. The authors calculate private and social costs for nine separate payment instruments. They find that, from a social cost perspective, cash is the cheapest payment instrument, followed by various electronic payment methods. From a private perspective, cash and checks emerge as the cheapest payment methods. Humphrey and Berger argue that because payers using credit cards and checks benefit from float, they tend to "overuse" these payment methods - a market failure that could be overcome with government intervention. ${ }^{3}$ Humphrey and Berger's analysis focuses exclusively on costs. Although they acknowledge that "convenience and acceptability" may play a role in payment instrument choice, in their calculations they omit the benefits that accrue from using different payment systems.

Wells (1996) extends the Humphrey-Berger study. She argues that Humphrey and Berger underestimate the social cost of checks. She also observes that check use did not fall between 1987 and 1993, even though the value of float fell, calling into question the overuse hypothesis. Like Humphrey and Berger, Wells focuses on costs and acknowledges that benefits matter - particularly in her discussion of why checks are used more frequently than less costly alternatives - but does not attempt to measure any of these benefits.

Humphrey et al. (1996) analyze patterns in the use of cash and other paper and electronic payment instruments in 14 developed countries, including the U.S, for 19871993. They find that the calculated prices of payment instruments fail to explain differences in instrument use across countries and over time. They also find that "institutional variables" - in particular the violent crime rate - explain a non-trivial portion of the observed differences in usage across countries. Crime could be interpreted instead as an indirect cost. Unlike payment cards and checks, which bear the owner's name and therefore require a degree of sophistication to use without authorization, stolen cash is perfectly transferable. The authors' finding confirms the importance of considering probabilistic costs like the perceived risk of theft.

Humphrey et al. (2003) is a more recent survey of the payment cost literature. The authors suggest that a country could save 1 percent of its GDP annually by shifting from a fully paper-based to a fully electronic-based system. Costs are presented at countryspecific/instrument-specific average transaction sizes, however, making cross-country and cross-instrument comparisons difficult. Some of the comparisons also omit certain parties to transactions, namely central banks and consumers, most likely due to missing data. Finally, because the literature does not quantify benefits, Humphrey et al.'s survey does not either.

\footnotetext{
${ }^{3}$ This point does not necessarily follow, though, since payment card systems are two-sided markets. Payment card pricing and cost-sharing arrangements help to get both of the crucial parties to the transaction to participate. See Evans (2003) at pp. 357-358. For a theoretical treatment of two-sided market issues, see Rochet and Tirole (2003); and Parker and Van Alstyne (2000). Because the payment card system needs to balance overall demand, the prices charged to any one side will not generally equal the marginal cost on that side, if indeed marginal costs can even be separated by sides. See Schmalensee (2002).
} 
A paper by Stavins (1997) is one of the first to include benefits as well as costs. Stavins examines the transition from traditional check clearing to electronic check "presentment and truncation". ${ }^{4}$ Stavins concludes that electronic check processing would raise net social benefits by a substantial amount (2.39 cents per check or $\$ 1.4$ billion per year), although transition costs and other obstacles may stand in the way of easy adoption.

A handful of other studies do not evaluate costs at all, but focus instead on benefits. Carow and Staten (1999) survey gas and store-cardholders on why they choose to pay with general-purpose payment cards. The authors find that the convenience of using a single payment card and the potential to earn rebates are among the primary reasons for using a bankcard. Mantel (2000) summarizes the literature on consumer payment decision-making, also focusing on payer benefits. He proposes a framework in which three factors explain the private use of electronic banking: consumer wealth; personal preferences, such as convenience and privacy; and transaction-specific factors, such as the transaction size. In similar work on electronic payment instrument decisions, MacKie-Mason and White (1996) show how a decision-maker may follow a systematic approach to selecting a payment mechanism. They conclude that only a handful of payment instrument characteristics likely play a dominant role in the selection process.

The majority of the empirical academic studies focus either exclusively or mainly on the cost of payment instruments. This is likely due to the difficulty in defining and measuring the benefits that various payment instruments provide. Some studies hint that benefits such as convenience matter, but they do not develop the implications of this insight. Stavins (1997) is the only U.S. study, to our knowledge, that makes a systematic attempt to measure costs and benefits for all parties involved, but her study focuses exclusively on check processing. While cost considerations are necessary, they are not sufficient for making sound policy recommendations. The challenge is to systematically study the costs and benefits of various payment methods, taking as many costs and benefits as possible into account for all parties involved.

\section{Clarifying the cost-benefit approach}

Here we clarify the focus of our cost-benefit analysis. We could, for example, try to position ourselves in a world without payment cards, or electronic payment methods more generally, and pose the question: Would the introduction of these payment instruments be beneficial to society?

Adopting this approach would be analogous to addressing the traditional issue of whether a bridge over a river should be constructed or not, when people are used to crossing the river by ferry (Layard and Glaister, 2001). If we were to closely follow this approach, the cost-benefit calculations would proceed in three steps. First, we would calculate the net cost of using the new alternative on a per-transaction basis and would compare it with the net cost of using the old method. (Note that in the case of payment instruments the calculations would be somewhat more complicated than in the case of the bridge, since payment methods are two-sided platforms.) Second, assuming that the perunit net benefit (that is benefits net of costs) of using the new alternative is higher than the

\footnotetext{
${ }^{4}$ With electronic check truncation, the physical transfer of the original paper check to the paying bank is terminated. Instead, the check is electronically presented to the paying bank (and all the other processors in between) by sending an electronic image of the check.
} 
per-unit net benefit of the old method, we would calculate the expected discounted flow of net benefits that would accrue to society over the relevant period of time. Potentially, there would be net benefits not only because the transactions that were already taking place would be conducted at a lower net social cost, but also because transactions that were not happening before would now take place. Finally, we would compare the sum of these discounted net benefits with the up-front cost of building the new alternative (the paymentcard system), and would determine whether it makes sense for society to introduce the new alternative or not.

This approach is not available for a study of payment instruments today. For all practical purposes, the bridge has been constructed already - payment cards, and electronic payment instruments more generally, are pervasive. Furthermore, recovering information on how much it cost to build the system would be a monumental task at this stage. In addition to observing that the system is in place today, we also observe that payment cards, and electronic instruments more generally, have been replacing paper instruments for many years.

Table 1 illustrates that payment card use (whether credit, charge or debit) has increased significantly over the last decade. This shift holds for every single transaction size. ${ }^{5}$ In contrast, the use of paper instruments - cash and checks - has declined significantly for every single transaction size. ${ }^{6}$

\begin{tabular}{|c|c|c|c|c|c|c|c|c|c|}
\hline & \multicolumn{9}{|c|}{ Transaction Size } \\
\hline & $\$ 5-10$ & $\$ 10-20$ & $\$ 20-40$ & $\$ 40-60$ & $\$ 60-80$ & $\$ 80-100$ & $\$ 100-500$ & $\$ 500+$ & Overall \\
\hline Credit/Charge & 5 & 5 & 11 & 6 & 6 & 5 & 2 & 3 & 5 \\
\hline Debit & 11 & 15 & 16 & 14 & 14 & 12 & 10 & 5 & 10 \\
\hline Card Total & 16 & 19 & 27 & 20 & 20 & 17 & 13 & 8 & 15 \\
\hline Cash & -10 & -11 & -8 & -6 & -5 & -4 & -2 & 1 & -4 \\
\hline Checks & -7 & -11 & -22 & -19 & -20 & -18 & -16 & -10 & -12 \\
\hline Paper Total & -17 & -22 & -30 & -25 & -25 & -22 & -18 & -9 & -16 \\
\hline
\end{tabular}

Table 1: The percentage point change in transaction shares by transaction size, 19962004

Notes: Debit includes both signature and PIN debit. Other instruments, including ACH and EFT, are excluded so the card and paper totals will not net to zero. Numbers may not add due to rounding. Source:Visa U.S.A. (2005)

In light of these events, we have chosen to address a different question: Is society better off when people conduct an additional transaction on payment cards rather than on paper instruments? The fact that consumers are choosing to pay more often with payment cards when they could continue to pay with checks or cash implies that they are better off.

\footnotetext{
${ }^{5}$ As payment choices changes, economies of scale force other changes. For instance, the decline in check use has led the Fed to close check-processing stations in the recent past. Electronic payment methods, on the other hand, probably still benefit from increasing returns to scale as more merchants (such as fast food restaurants) accept card payments.

6 The one exception is cash for $\$ 500+$ transactions.
} 
The question is whether economic welfare increases when the calculation includes other groups, such as merchants and banks. If consumers do not face the full price of using a payment card, a point made by several scholars (for example, Humphrey and Berger, 1990; Chakravorti, 2002; and Rochet and Tirole, 2002), then what is good for consumers might not be good for the economy as a whole.

This approach requires that we examine the incremental transaction and pose the following question. What are the costs and benefits of this transaction, conducted using different payment instruments, for each one of the parties involved? In order to properly address this question, we need to consider three issues. First, we need to take all parties into account. Payment instruments that are beneficial, on net, for one of the actors may not be for society as a whole. Second, we need to carefully distinguish true resource costs from transfer payments. Third, we need to count both cost and benefits for all participants.

The strengths of our exercise, in comparison with earlier cost accounting attempts, are twofold: we systematically consider all parties to a transaction, and we calculate the value of benefits and costs rather than costs only.

Before presenting the calculations we briefly discuss the limitations of our approach. First, in our empirical analysis we are assuming that a given transaction will occur regardless of the payment method decision. This conditional approach examines costs and benefits of payment instruments under the assumption that a transaction will take place with certainty at a given size and in a specific context. An alternative unconditional approach, analogous to general equilibrium analysis, takes into account the possibility that the size and location of a transaction can vary, as can the overall level of transactions. For instance, the Internet frequently provides consumers with an alternative to shopping in a physical store.

One benefit of using an unconditional approach is that it can capture the transaction cost savings inherent in changing how a purchase occurs. For example, when merchants expand the menu of payment instruments allowed, consumers can get closer to their preferred method of paying in their preferred retail venue. Eliminating the search for a store that accepts a preferred payment instrument lowers transaction costs. Reduced transaction costs then free resources for additional consumption or savings.

In our empirical analysis we use a conditional approach. However, it is important to recognize that the assessment of the relative costs and benefits could change significantly with the application of an unconditional approach - just as in comparisons of net benefits using partial and general equilibrium analysis (Goulder and Williams, 2003).

Second, even though we have tried to take heterogeneity into account, it is likely that we have not gone far enough. In the real world, the evidence suggests that, even for a given transaction size, many different payment instruments are used. Figure 1 shows the percentage of 2004 consumer-to-business transactions (by sales volume) paid for by payment cards and paper instruments, broken out by transaction size. 


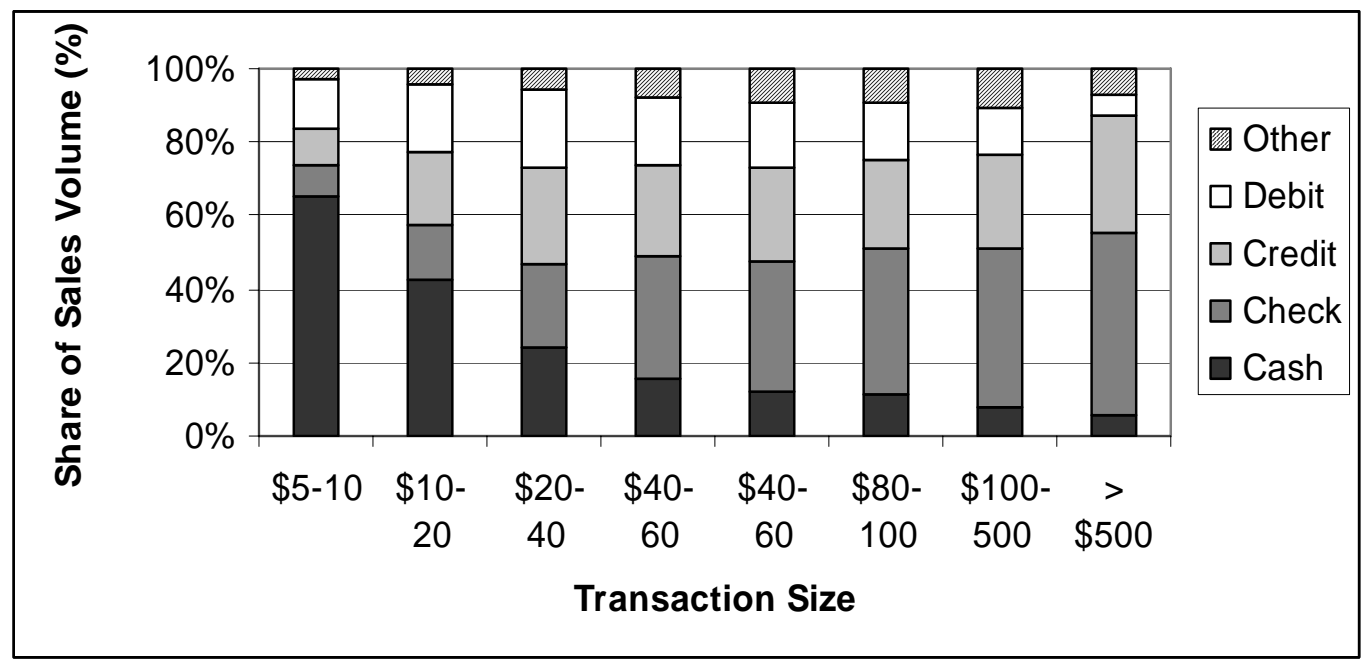

Figure 1: Payment instrument transaction shares at various sizes for 2004

Note: Debit includes both signature and PIN debit. Charge cards are included with credit. Source: Visa U.S.A. (2005)

The figure reveals that a wide mix of instruments is used for transactions at a given size. Even though cash is more widely used for small size transactions it is not the only instrument used. Various factors account for this payment instrument use at a given transaction size, and surely consumer and merchant heterogeneity are key among them. Consumers, for example, vary in income and wealth. Individuals with higher labor incomes may have a higher opportunity cost of time and may be willing to pay more for a transaction that is faster. ${ }^{7}$ Merchants are heterogeneous as well. For example, a discount retailer with multiple checkout lanes will face different costs and benefits when accepting personal checks or PIN debit cards than a boutique retailer with only one payment register. ${ }^{8}$

In our empirical analysis we try to account for two types of heterogeneity. First, we consider various transaction sizes, thus acknowledging the possibility that costs and benefits may vary depending on transaction amount. Second, we consider transactions at different types of merchants. In other words, we take into account merchant heterogeneity to the extent that the data allow us to. As far as consumers are concerned, the data limit us to analyzing a representative consumer. ${ }^{9}$

The existence of heterogeneous consumers and merchants raises a third issue for interpreting the cost and benefit numbers. Throughout our study we use the terms "marginal costs" and "marginal benefits." Strictly speaking, we are calculating pertransaction incremental costs and benefits for a typical consumer or merchant of a

\footnotetext{
${ }^{7}$ Heterogeneity may exist not only across consumers, but also across transactions for a given consumer.

${ }^{8}$ Most debit cards can be used for either PIN or signature debit - the transaction distinction is made at the processing level. If a debit card receipt is signed for authorization it is referred to as signature debit and is processed at the point of sale using standard credit and charge card readers. When a debit card receipt is authorized with a personal identification number (PIN debit), a special PIN reader must be used.

${ }^{9}$ We explore the sensitivity of our results for key parameters, such as the value of time, in Garcia-Swartz et al. (2006b). Our qualitative results are generally robust to changes in the key parameters.
} 
particular type. ${ }^{10}$ If data were available, we would prefer to estimate marginal benefits and costs for a set of heterogeneous consumers and merchants involved in different types of transactions. Because of data limitations, we rely on sensitivity analysis to explore the robustness of our main conclusions. ${ }^{11}$

\section{$4 \quad$ Empirical estimates}

To demonstrate the importance of moving beyond costs, we develop three case studies that start with earlier cost analyses, but are expanded to cover multiple parties and to include benefits. We focus our analysis on the tendency of consumers to make greater use of payment cards over time. Because the location of a transaction influences the cost and benefit calculations, we analyze social net benefits in two specific retail venues: grocery stores and electronics specialty stores. These venues cover a range of goods and average prices. As one might expect, payment instrument use varies over time and by venue. For example, the share of cash and check use has declined dramatically at grocery stores, from nearly 90 percent in 1994 to under 60 percent by 2001. In place of paper instruments, the share of payment card use has increased - especially debit cards, which accounted for around 20 percent of grocery store volume by 2001. A different picture emerges at electronics specialty stores: cash was never an important payment instrument (accounting for less than 10 percent of purchases) while credit is by far the most frequently used method (hovering near 60 percent throughout the 1990s). Transaction size likely plays a large role here - the average electronics purchase is several times higher than the average grocery purchase.

We begin our analysis with merchant cost estimates sponsored by industry participants and used in previous academic studies. Then we fix transaction size, broaden the analysis to include all parties to a transaction, and quantify benefits where possible. We highlight the dramatic changes that these modifications bring: those instruments that appear expensive to merchants are often relatively inexpensive for the economy as a whole.

The following equations, based on an extension of the model developed by Baxter (1983), define the case study exercise below. Let C denote resource costs and B denote benefits for a payment card transaction relative to cash. The sub- and superscripts $\mathrm{m}, \mathrm{c}, \mathrm{b}$,

\footnotetext{
${ }^{10}$ Some of our data sources allow only for average figures, such as commercial bank processing costs. We exclude costs that do not vary per transaction, such as the marketing expenditures made by commercial banks for checking accounts, credit cards, and debit cards.

${ }^{11}$ Furthermore, note that, even though we try to take certain externalities into account (for example, the negative externality imposed by someone paying at the counter on someone else waiting in line), our calculations do not incorporate the Rochet-Tirole "main externalities" of cardholders on merchants and of merchants on cardholders. First, a merchant that does not accept a payment card generates a negative externality for cardholders. Second, cardholders may not internalize the merchants' welfare. In the RochetTirole framework, the merchants' acceptance decision depends on the average net benefit that cardholders enjoy. By definition, the average cardholder net benefit from using the card is higher than the marginal net benefit, which is zero. As a consequence, in this framework the merchants' opposition to cards may be too weak, and certain card transactions may happen that should not have happened from the perspective of social efficiency. (They should not have happened because the net benefit that the cardholder obtains from them is smaller than the loss that the merchant experiences.) As Rochet and Tirole put it: "That is, the cardholder's lack of internalization of the merchant's loss (which itself is based on the merchant's internalization of cardholders' welfare!) may lead to inefficient card transactions” (Rochet and Tirole, 2006).
} 
and g denote merchants, consumers, commercial banks, and the government, respectively. We can define $P^{c}=P_{b}^{c}+P_{g}^{c}$ as the explicit price that consumers face when making a transaction with a payment card relative to cash, where $P_{b}^{c}$ is the price they pay to commercial banks and $P_{g}^{c}$ is the price they pay to the government, both prices relative to cash. Then, consumers are better off using cards if and only if

$$
B^{c}>C^{c}+P_{b}^{c}+P_{g}^{c}
$$

In other words, consumers are better off if the (private) benefits they obtain from a card transaction (relative to cash) are larger than their (private) resource costs of conducting a card transaction relative to cash plus the relative explicit price they pay for the card transaction. Consumers will choose to pay with cards only when equation (1) holds.

Similarly, merchants weigh the benefits of cards relative to cash against the relative resource costs of processing a card transaction plus the explicit fees they must pay to commercial banks:

$$
B^{m} \geq C^{m}+P_{b}^{m}
$$

Commercial banks, in turn, weigh their private benefits and costs, again all relative to cash:

$$
B^{b}=P_{b}^{m}+P_{b}^{c} \geq C^{b}
$$

The analogous equation for the government is:

$$
P_{g}^{c} \geq C^{g}
$$

Taking these four private comparisons and netting out transfers between the parties yields the following social equation:

$$
B^{c}+B^{m} \geq C^{c}+C^{m}+C^{b}+C^{g}
$$

If condition (5) is met, then society is better off when a payment card transaction replaces a cash one. In the tables below, we present estimates for the costs and benefits facing these four parties to a transaction.

Calculations like the ones presented below can convey a false sense of precision. In order to highlight the often small differences in costs and benefits across payment instruments, we report figures to the nearest cent. Most of these numbers are estimates. While the analysis represents careful accounting, all numbers should be interpreted as suggestive but not definitive.

\subsection{Replacing cash and checks at the grocery counter}

The first case study examines whether the shift toward increased payment card use in grocery stores has resulted in economic welfare gains. ${ }^{12}$ We begin with the Food Marketing Institute (1998) cost study, which surveyed grocers on the marginal costs of accepting various payment instruments. Costs vary considerably among grocery stores as a function of size, geographic location, age and sophistication of the equipment used. FMI

\footnotetext{
${ }^{12}$ For details on the calculations made in the case studies that follow, as well as for data sources and sensitivity analysis, see the companion paper Garcia-Swartz et al. (2006b).
} 
therefore reported high, low, and average costs based on its survey; we use average costs here.

Table 2 presents merchant processing costs for grocery stores. A couple of items should be highlighted. First, following standard practice (for now), the per-transaction costs in each cell of Section A are calculated for a different transaction size: the average size for the given payment instrument. Certain costs, such as some bank charges, are sensitive to the purchase amount, so costs presented this way are difficult to compare. Second, the relative costs of the various payment instruments change considerably when the costs are translated to $\$ 100$ of sales (see Section B). This method of scaling - another industry study standard - multiplies the costs per average transaction by the constant necessary to reach $\$ 100$ of sales, thus assuming all costs vary linearly.

\begin{tabular}{|c|c|c|c|c|c|c|c|}
\hline & & Cash & $\begin{array}{l}\text { Non- } \\
\text { Verified } \\
\text { Check }^{*}\end{array}$ & $\begin{array}{l}\text { Verified } \\
\text { Check }\end{array}$ & $\begin{array}{l}\text { Credit/ } \\
\text { Charge }\end{array}$ & $\begin{array}{l}\text { Signature } \\
\text { Debit }\end{array}$ & PIN Debit \\
\hline \multirow[t]{7}{*}{ Section A } & Theft/Counterfeit & 0.03 & 0 & 0 & 0 & 0 & 0 \\
\hline & Float & 0.001 & 0.01 & 0.01 & 0.01 & 0.01 & 0.003 \\
\hline & Tender Time & 0.11 & 0.26 & 0.24 & 0.18 & 0.18 & 0.17 \\
\hline & Deposit Preparation & 0.004 & 0.03 & 0.03 & 0 & 0 & 0 \\
\hline & Bank Charges & 0.004 & 0.06 & 0.16 & 0.94 & 0.56 & 0.41 \\
\hline & Other Direct Costs & $\underline{0.16}$ & 0.27 & 0.03 & 0.02 & 0 & 0 \\
\hline & Marginal Costs & 0.30 & 0.64 & 0.47 & 1.15 & 0.75 & 0.57 \\
\hline \multirow[t]{2}{*}{ Section B } & $\begin{array}{l}\text { Average Purchase } \\
\text { for Payment Type }\end{array}$ & 11.52 & 54.24 & 54.24 & 44.50 & 33.00 & 41.05 \\
\hline & $\begin{array}{l}\text { Cost Scaled to } \$ 100 \\
\text { of Sales }\end{array}$ & 2.61 & 1.17 & 0.86 & 2.58 & 2.27 & 1.40 \\
\hline \multirow[t]{2}{*}{ Section C } & $\begin{array}{l}\text { Marginal Costs, } \\
\text { Cash Transaction } \\
\text { Size } \$ 11.52\end{array}$ & 0.30 & 0.42 & 0.44 & 0.61 & 0.68 & 0.57 \\
\hline & $\begin{array}{l}\text { Marginal Costs, } \\
\text { Check Transaction } \\
\text { Size } \$ 54.24\end{array}$ & 0.43 & 0.64 & 0.47 & 1.22 & 0.82 & 0.57 \\
\hline
\end{tabular}

Table 2: Per transaction processing costs for various payment instruments grocery store merchants (\$)

Notes: Numbers may not add due to rounding. Float costs are calculated as interest foregone from the date of sale to the payment - method-specific date of clearance. Tender time is the labor cost from the time the total amount is displayed on the cash register to the time payment is consummated. Deposit preparation measures the labor costs of preparing a typical bank deposit for a merchant's bank account. Electronic payment methods are cleared online at the point of sale and therefore do not involve any deposit preparation. Bank charges are explicit fees, such as a deposit fee for cash and checks or processing fees for payment cards. This includes the "merchant discount" fee assessed by commercial banks for payment card transactions. Other direct costs capture miscellaneous costs associated with each type of payment, such as check losses and collection fees, credit card losses (including "charge backs”), and armored car costs for transporting cash to the bank.

*Non-verified checks are manually authorized at the checkout counter. Verified checks are electronically authorized to have sufficient funds in the account to cover the purchase.

Source:FMI (1998) survey and authors' calculations. 
Linear scaling of costs is misleading because some costs do not vary at all with transaction size while others vary in a non-linear way. We therefore calculate costs for two fixed transaction sizes in Section C of Table $2 .{ }^{13}$ Using a fixed transaction size induces a dramatic change in terms of relative payment instrument costs. Taking the typical cash transaction size, the marginal cost of credit and signature debit cards fall considerably as compared to the marginal cost reported in Section A. For the typical check transaction size, however, credit cards are around twice as expensive for merchants as checks. Cash remains the cheapest method for grocery store merchants at each transaction size.

The costs reported in Table 2 say nothing about whether economic benefits result when payment cards replace cash and checks for grocery purchases. Two adjustments are needed to analyze the welfare changes that shifts in payment methods can generate. First, we need to consider other parties involved in the transaction. Second, we need to calculate the benefits accruing to the parties involved.

\subsubsection{Adding other parties to the transaction}

Table 3 adds the cost of using a payment instrument for consumers and the cost of processing the payment for the Federal Reserve and commercial banks. The first number in each cell bases the calculation on the grocery average cash transaction size of \$11.52 and the second number bases it on the average check size of \$54.24.

The first group added is consumers. Consumers making a purchase face an opportunity cost for the time spent at the register while a transaction is processed ("Processing Time”). ${ }^{14}$ In addition, consumers waiting in line face an opportunity cost for their time while the current payer's transaction is being conducted, captured by "Queue Time”. We measure these costs as the average U.S. wage rate multiplied by the payment processing time. ${ }^{15}$ In-network ATM fees for cash withdrawal (own bank) are the explicit cost to consumers of getting cash, scaled by the percentage of consumers facing such fees. To the extent that consumers access off-network ATMs, we are understating the explicit price for cash paid by consumers. The explicit cost of checks is the purchase price of a paper check.

As the last cost item for consumers, we add the implicit cost of obtaining cash. This cost consists of the typical amount of time that consumers spend in making a trip to an ATM multiplied by the average U.S. wage rate. ${ }^{16}$ Note that the implicit cost of cash increases dramatically with transaction size. The average cash withdrawal is $\$ 60$, which translates into six small transactions of $\$ 10$, but only one transaction of $\$ 50$, with the full time cost applied to that one purchase. Of course, knowing that they have to make a larger purchase, consumers could increase their withdrawal amount, up to a maximum of $\$ 200$ or $\$ 300$ usually. However, as the amount of cash carried increases, so too does the risk of loss or theft. We also know from Figure 1 that less than 20 percent of the \$40-60 transactions

\footnotetext{
${ }^{13}$ The fact that the average transaction size for cash differs from that for checks (and payments cards, as well) indicates that consumer preferences for payment mechanisms vary by transaction size. Whitesell (1989) develops a model that explains some of the preference differences. See also, Santomero and Seater (1996).

${ }^{14}$ Klee (2004) finds that debit card use in grocery store transactions increases with the difference in processing time as compared to checks.

${ }^{15}$ Because this measure may either under or overstate the true opportunity cost of time, we test the sensitivity of our results to changes in the wage rate.

${ }^{16}$ For consumers using point of sale cash-back (primarily with PIN debit) or other faster means of obtaining cash, this estimate could be an overstatement. For other consumers, obtaining cash may take more time and the estimate could be an understatement. When consumers drive to an ATM, they incur a driving cost in addition to time. We do not include this cost, which will also understate our estimate.
} 
are paid for with cash, at least partly due to the increased costs of carrying large amounts of cash. Taking all of these factors into account, we choose a moderate option of doubling the cash withdrawal amount to $\$ 120$, allowing for over two transactions per ATM trip, as the basis of our implicit cost calculation for the larger transaction size. ${ }^{17}$

The central bank is the second party added to the calculations. The Federal Reserve incurs production costs for cash, which we translate into a per-dollar cost. It also incurs handling costs for cash. Unlike metal coins, cash has a short lifespan. With each transaction, a bill becomes more soiled and worn. The central bank maintains the quality of paper currency, removing any unfit bills. The Federal Reserve provides this service, subsidizing the use of cash by coordinating supplies for banks and maintaining a high level of currency quality, without charge to consumers or commercial banks (Lacker, 1993). ${ }^{18}$ We therefore include the central bank's per-transaction cost of processing and replacing cash as a marginal cost. Federal Reserve Banks also act as intermediaries in check processing for commercial banks, passing these costs on in full to the banks.

Commercial Banks are the third and final party added to the calculations. ATM machines must be maintained and refilled with cash periodically. We allocate monthly maintenance costs across the number of potential transactions generated by monthly withdrawals to estimate the per-transaction ATM cost. Just as with paper currency, the magnetic stripe on plastic payment cards wears out over time and must be replaced, typically every two years. For commercial bank check processing costs, we report pertransaction in-house costs plus processing fees paid to intermediaries such as the Federal Reserve. Commercial banks also incur processing costs for payment cards. For example, card issuers fund consumer credit card float for an average of 25 days, paying merchants within a day or so but receiving cardholder payment nearly a month after the purchase date. ${ }^{19}$ Acquirers expend resources to facilitate transaction clearing between card issuers and merchants. Finally, commercial banks must fund the payment card reward programs they offer consumers.

\footnotetext{
${ }^{17}$ The implicit cost of obtaining cash if the $\$ 60$ average withdrawal is maintained for the larger purchase size is $\$ 1.30$. If the maximum allowable cash extraction of $\$ 300$ is used, the implicit cost of obtaining cash for the $\$ 54$ purchase is 26 cents. Our assumption of a $\$ 120$ withdrawal is unavoidably arbitrary.

${ }^{18}$ The question of subsidization has been raised for several different payment instruments. Humphrey and Berger (1990) assert that consumer check and credit card use are both subsidized (by commercial banks in the case of checks and indirectly by merchants in the case of credit cards). It appears that commercial banks subsidize PIN debit use as well. The ATM networks operating PIN debit designed the price structure with relatively low interchange fees as compared to signature debit and credit cards in part to provide merchants with an incentive to lease and install special PIN pad equipment. Signature debit transactions, on the other hand, are processed using credit card equipment already in place at most merchants. Today, however, after many merchants have already installed PIN pad equipment, debit-processing banks appear concerned they are not covering costs with PIN interchange fees.

${ }^{19}$ The cost of funds for float only applies to those credit card customers current with their bills. Customers with outstanding credit pay interest on purchases immediately.
} 


\begin{tabular}{|c|c|c|c|c|c|c|}
\hline & Cash & $\begin{array}{l}\text { Non-Verified } \\
\text { Check }\end{array}$ & $\begin{array}{l}\text { Verified } \\
\text { Check }\end{array}$ & $\begin{array}{l}\text { Credit/ } \\
\text { Charge }\end{array}$ & $\begin{array}{l}\text { Signature } \\
\text { Debit }\end{array}$ & PIN Debit \\
\hline $\begin{array}{l}\text { a) Merchant Marginal } \\
\text { Costs (Table 2) }\end{array}$ & $.30, .43$ & $.42, .64$ & $.44, .47$ & $.61,1.22$ & $.68, .82$ & $.57, .57$ \\
\hline Consumer & & & & & & \\
\hline Processing Time & $.14, .14$ & $.33, .33$ & $.31, .31$ & $.23, .23$ & $.23, .23$ & $.21, .21$ \\
\hline Queue Time & $.14, .14$ & $.33, .33$ & $.31, .31$ & $.23, .23$ & $.23, .23$ & $.21, .21$ \\
\hline Explicit Price & $.03, .03$ & $.04, .04$ & $.04, .04$ & 0,0 & 0,0 & $.13, .13$ \\
\hline Implicit Price & $.28,0.65$ & 0,0 & 0,0 & 0,0 & 0,0 & 0,0 \\
\hline Seigniorage & $.07, .33$ & 0,0 & 0,0 & 0,0 & 0,0 & 0,0 \\
\hline $\begin{array}{l}\text { b) Consumer Marginal } \\
\text { Costs }\end{array}$ & $.65,1.27$ & $.70, .70$ & $.65, .65$ & $.46, .46$ & $.46, .46$ & $.55, .55$ \\
\hline $\begin{array}{l}\text { Central Bank } \\
\text { Production }\end{array}$ & $.001, .01$ & 0,0 & 0,0 & 0,0 & 0,0 & 0,0 \\
\hline Processing & $.002, .002$ & $.03, .03$ & $.03, .03$ & 0,0 & 0,0 & 0,0 \\
\hline $\begin{array}{l}\text { c) Central Bank Marginal } \\
\text { Costs }\end{array}$ & $.004, .01$ & $.03, .03$ & $.03, .03$ & 0,0 & 0,0 & 0,0 \\
\hline $\begin{array}{l}\text { Commercial Bank } \\
\text { ATM Maintenance }\end{array}$ & $.06, .30$ & 0,0 & 0,0 & 0,0 & 0,0 & 0,0 \\
\hline Production & 0,0 & 0,0 & 0,0 & $.01, .01$ & $.01, .01$ & $.01, .01$ \\
\hline Processing & $.004, .02$ & $.12, .12$ & $.12, .12$ & $.27, .40$ & $.26, .34$ & $.26, .34$ \\
\hline Reward Cards & 0,0 & 0,0 & 0,0 & $.05, .24$ & 0,0 & 0,0 \\
\hline $\begin{array}{l}\text { d) Commercial Bank } \\
\text { Marginal Costs } \\
\end{array}$ & $.07, .31$ & $.12, .12$ & $.12, .12$ & $.34, .65$ & $.27, .35$ & $.27, .35$ \\
\hline e) Sum of Marginal Costs & $1.02,2.02$ & $1.27,1.49$ & $1.24,1.27$ & $1.41,2.33$ & $1.42,1.63$ & $1.40,1.48$ \\
\hline f) Social Marginal Costs & $.99,1.98$ & $1.18,1.40$ & $1.05,1.08$ & $0.99,1.32$ & $.92,1.00$ & $.86, .94$ \\
\hline
\end{tabular}

Table 3: Private and social marginal costs grocery cash (\$11.52) and check (\$54.24) transaction sizes (\$)

Notes: The first and second numbers in each cell correspond to the lower and higher transaction sizes, respectively. Numbers may not add due to rounding. Sum of Marginal Costs, e, is equal to a $+b+c$ + d. Due to transfers across parties (such as merchant payments to commercial banks), the sum double counts some cost elements. Social Marginal Costs, f, eliminates transfers to avoid double counting.

Source:Authors' calculations.

At the cash transaction size, the costs in Table 3 for all payment types are relatively close to one another. In Table 2, the spread between the most and least expensive instruments was nearly 87 cents; in Table 3 that spread is only around 41 cents. Moreover, cash - the cheapest instrument for merchants - is not the cheapest instrument for the economy as a whole, at either the smaller or the larger transaction size. Counting all parties, PIN debit transactions are cheapest, followed closely by signature debit. For the 
smaller transaction, cash is third and credit is fourth. But for the larger transaction, paper instruments, especially cash and non-verified checks, emerge as more costly forms of payment. Thus adding other parties to the transaction has changed the relative cost situation considerably.

\subsubsection{Quantifying benefits}

We now turn to our next key adjustment: quantifying the benefits of payment instruments. Table 4 presents the results.

\begin{tabular}{|c|c|c|c|c|c|c|}
\hline & Cash & $\begin{array}{l}\text { Non- } \\
\text { Verified } \\
\text { Check }\end{array}$ & $\begin{array}{l}\text { Verified } \\
\text { Check }\end{array}$ & $\begin{array}{l}\text { Credit/ } \\
\text { Charge }\end{array}$ & $\begin{array}{l}\text { Signature } \\
\text { Debit }\end{array}$ & PIN Debit \\
\hline \multicolumn{7}{|l|}{ Consumers } \\
\hline Float & 0,0 & $.002, .01$ & $.002, .01$ & $.01, .04$ & 0,0 & 0,0 \\
\hline Credit Option & 0,0 & 0,0 & 0,0 & $.03, .02$ & 0,0 & 0,0 \\
\hline Record Keeping & 0,0 & $.04, .04$ & $.04, .04$ & $.04, .04$ & $.04, .04$ & $.04, .04$ \\
\hline Cash Back Option & 0,0 & $.15, .15$ & $.15, .15$ & 0,0 & 0,0 & $.13, .13$ \\
\hline Signature Debit & 0,0 & 0,0 & 0,0 & 0,0 & $.13, .13$ & 0,0 \\
\hline Reward Cards & 0,0 & 0,0 & 0,0 & $.10, .48$ & 0,0 & 0,0 \\
\hline Discover Cards & 0,0 & 0,0 & 0,0 & $.003, .02$ & 0,0 & 0,0 \\
\hline Privacy & $.12, .54$ & 0,0 & 0,0 & 0,0 & 0,0 & 0,0 \\
\hline Consumer Marginal Benefits & $.12, .54$ & $.19, .19$ & $.19, .19$ & $.18, .60$ & $.16, .16$ & $.16, .16$ \\
\hline \multicolumn{7}{|l|}{ Central Bank } \\
\hline Seigniorage & $.07, .33$ & 0,0 & 0,0 & 0,0 & 0,0 & 0,0 \\
\hline $\begin{array}{l}\text { Central Bank Marginal } \\
\text { Benefits }\end{array}$ & $.07, .33$ & $.03, .03$ & $.03, .03$ & 0,0 & 0,0 & 0,0 \\
\hline $\begin{array}{l}\text { Commercial Bank } \\
\text { Float }\end{array}$ & 0,0 & 0,0 & 0,0 & 0,0 & $.002, .01$ & $.001, .004$ \\
\hline Processing Revenue & $.03, .05$ & $.06, .06$ & $.16, .16$ & $.42,1.01$ & $.50, .63$ & $.54, .54$ \\
\hline $\begin{array}{l}\text { Commercial Bank Marginal } \\
\text { Benefits }\end{array}$ & $.03, .05$ & $.06, .06$ & $.16, .16$ & $.42,1.01$ & $.50, .64$ & $.54, .54$ \\
\hline Sum of Marginal Benefits & $.22, .92$ & $.28, .28$ & $.38, .38$ & $.62,1.62$ & $0.66,0.80$ & $.57, .57$ \\
\hline $\begin{array}{l}\text { Sum of Marginal Costs } \\
\text { (Table 3) }\end{array}$ & $1.02,2.02$ & $1.27,1.49$ & $1.24,1.27$ & $1.42,2.33$ & $1.42,1.63$ & $1.40,1.48$ \\
\hline Net Social Marginal Costs & $.80,1.11$ & $.99,1.21$ & $.87, .89$ & $.80, .72$ & $.76, .83$ & $.70, .78$ \\
\hline
\end{tabular}

Table 4: Adding selected benefits grocery cash (\$11.52) and check (\$54.24) transactions (\$)

Notes: The first and second numbers in each cell correspond to the lower and higher transaction sizes, respectively. Numbers may not add due to rounding. Net Social Marginal Costs equal the Sum of Marginal Costs minus the Sum of Marginal Benefits, which eliminates transfers across the parties (such as merchant payments to commercial banks for check processing). 
Source: Authors' calculations.

Table 4 adds estimates of per-transaction benefits associated with each of the payment instruments at the cash and check transaction sizes. Checks and credit cards provide consumers with some level of float, calculated as the interest that could be earned before the transaction clears. Credit cards provide consumers with the greatest amount of float, assuming the consumer is current with his or her bills. On average, consumers with no outstanding credit have 25 days from the date of purchase to the date their credit card bill is due.

Credit cards also provide consumers with the option to borrow. ${ }^{20}$ Uncertainty over income or expenses can lead a consumer to rely on credit cards for payment, even if she intends at the time of purchase to pay the charge in full when her bill arrives. This benefit is difficult to measure because it varies with personal finances and available credit options. For instance, consumers who own their home and have accumulated some equity may qualify for a home equity loan through their bank. Home equity lines are a relatively lowcost credit option, but involve initial transaction costs and are unavailable to renters. In fact, all types of secured loans are generally unavailable to many consumers. Credit cards, on the other hand, offer a convenient source of unsecured credit to a broad cross section of consumers (Castronova and Hagstrom, 2004; and Nocera, 1994). Another unsecured credit alternative is the payday loan, but this is far more costly than credit card debt. ${ }^{21}$ An alternative relatively similar to credit cards is a personal line of unsecured bank credit. These credit lines typically have a minimum amount of several thousand dollars, but the interest rate terms are similar to credit cards. Once an unsecured line of credit is established, consumers must pay an annual fee to maintain it. This fee can be thought of as the option price of borrowing over the year. We allocate the fee across the minimum loan to obtain an estimate of the per-dollar option value benefit, scaled by the percentage of cardholders exercising the option. ${ }^{22}$

All payment methods except for cash provide consumers with a record keeping mechanism useful for budgeting, planning, and income tax preparation. Rather than having to keep track of each paper receipt, checks and payment cards provide itemized monthly statements; many also have online statements accessible anytime. We value this benefit using consumer survey data for analogous benefits.

Using checks and debit cards for grocery purchases can save consumers time outside of the checkout lane. Grocers commonly offer a cash-back option that is free of charge for these two payment instruments. As a result, consumers can reduce their need to make a

\footnotetext{
${ }^{20}$ Here we consider only the option value of obtaining credit, not the benefit of the credit itself net of the cost of funds. See Brito and Hartley (1995), at p. 402, who observe that credit cards "[provide] insurance against unanticipated shocks to expenditure or income”.

${ }^{21}$ A typical payday loan charges $\$ 17.50$ on every $\$ 100$ increment borrowed for each 15-day period. Thus a person borrowing \$200 for one month would pay \$70 in fees, which translates into an APR of 457 percent. ${ }^{22}$ As with the cash-back option for PIN debit cards, we scale this amount by the proportion of credit card users actually taking credit, which is around 55\% of all cardholders. The option of using credit is likely to have value at the time of purchase, even if the bill is paid in full when due. Nonetheless, unlike stock options, both the credit option and the cash-back option for PIN do not require any upfront purchase. There is therefore no signal of value when the option is not exercised.
} 
separate trip to an ATM to obtain cash for other purchases. We assume this benefit is equal to the implicit cost of obtaining cash from an ATM, scaled by the average cash-back amount and the percentage of debit transactions involving cash back. Signature debit cards offer benefits of their own, including card use similar to credit cards and broad merchant acceptance.

Around 43 percent of credit cardholders have cards that provide rewards of some kind, counting American Express, MasterCard, and Visa reward cards. Moreover Discover's cards offer "cash back". The most prevalent type of reward card grants consumers airline miles, typically with each dollar spent earning the cardholder one frequent flyer mile. We estimate the value of a ticket earned and then scale that value by the proportion of a ticket a grocery store transaction earns. Around 6 percent of all cardholders have a Discover card that operates under a point system, providing either cash back or coupons according to a fixed schedule. We calculate the cash back amount based on that schedule and the average Discover monthly card balance.

The last item listed for consumers is privacy. Some consumers worry that their purchases will be tracked if they pay with a check or plastic card that displays personal information. Cash provides consumers an anonymous method of paying. We estimate the privacy benefit that cash provides using loyalty card discounts. In supermarkets and many other stores, shunning a loyalty card means forgoing product discounts, which can be viewed as the implicit benefit of providing personal information. Consumers paying with cash (and not providing a loyalty card) must value their privacy at least as much as the discount forgone.

Governments earn a profit on the currency they produce. Seigniorage can be defined in many ways, but the definition we follow as it most closely matches our concept of benefits is fiscal seigniorage - the profit from printing currency net of expenses that the government actually has available for budgeting purposes (Neumann, 1992). That is, fiscal seigniorage is the difference between what it costs the government to produce currency and the face value of the currency which is then at the government's disposal. This "benefit" is analogous to the revenues collected by commercial banks: it represents a transfer (a tax) from cash-holding consumers to the Federal Reserve. As such, it is netted out in the social cost calculation. In addition, the Federal Reserve receives revenue from commercial banks to cover the cost of check processing.

Finally, commercial banks earn revenues for processing cash deposits, processing and clearing checks, and processing payment card transactions. They also benefit from float for debit cards: funds are typically withdrawn from consumers' accounts immediately, but payments to merchants take one to two days to finalize.

Taking all of the above benefits into account, the position of payment cards relative to cash and checks generally improves, as Table 4 illustrates, at least for the larger transaction size. For the cash transaction size PIN debit cards are the least expensive instrument; for the check transaction size credit cards are least expensive. Non-verified checks are one of the most expensive instruments, but are joined by cash at the higher transaction size. All of the payment instruments are remarkably close to one another at the smaller transaction size. And in fact, for the smaller transaction size the rank ordering of instruments is identical to that based on costs alone given in Table 3. At the larger transaction size, however, the rank ordering changes considerably, with the three payment cards ranking as cheaper than either of the two paper instruments. Thus, industry studies of merchants' costs do indeed present a misleading picture for policy makers. First, looking at individual 
average transaction sizes for each instrument masks some of the relative differences between payment types. Second, and more importantly, the ordering of payment instrument costs shifts significantly for larger transactions after multiple parties are added and benefits included.

Note that these calculations disregard the value of many other benefits that are difficult to quantify. For instance, payment cards offer the option of consolidating payments consumers charge everything on one card and pay only one bill at the end of the month. Many consumers value the enforced fiscal responsibility that cash, checks, and debit cards provide (Thaler, 1981; Stavins, 2001). Because these methods typically do not allow credit, they can help consumers to limit their debt. Checks and payment cards also provide improved theft and loss prevention as compared to cash, as well as easier dispute resolution in the event of problems. Credit and signature debit cards provide added protection because the card systems take an active role in dispute resolution. PIN debit does not provide this benefit as the money is immediately withdrawn from the consumer's bank account and any dispute resolution is left to the consumer and the merchant, just as with a cash purchase. For merchants, the ability to reverse charges on payment cards for returned goods, as opposed to providing cash refunds, could be a benefit as well. All of these benefits are important and help to explain the pattern of observed payment instrument use. The difficult nature of estimating their value implies that we cannot account for them in Table 4.

\subsection{The rise of debit cards at electronics specialty stores}

In our second case study, we consider electronics specialty stores. We start with another merchant cost study, this one conducted by Coopers \& Lybrand (1995). The Coopers study relied on cost data for one "representative" merchant for each segment considered. The cost estimates presented in this case study illustrate the effect that retail venue can have on payment instrument cost and benefit analysis. First, average transaction sizes are far higher in electronics specialty stores, as Table 5 illustrates. Second, the point of sale structure can be quite different. Many electronics stores do not have multiple checkout lanes positioned near the store exit. Moreover, even the large chains have been reluctant to accept PIN debit as the transactions require separate card readers. Thus, we would expect electronics store payment processing costs to be very different from grocery store costs.

The methods used to calculate non-merchant costs are identical to the grocery case. We therefore present only the merchant cost table and the net marginal social cost table, which covers all parties to the transaction and incorporates benefits.

Many cost elements are dramatically different than those for grocery store merchants, some higher and some lower. POS time costs are well below those for grocery stores - for example, the time cost for checks is lower by a factor of eight. Drawer/office costs are considerably higher for cash, but nearly identical for checks. Due to back office marginal costs, payment cards have non-zero drawer costs here. Bank charges are significantly higher as well, largely driven by the high average transaction sizes. Grocers reported an average cash purchase of around $\$ 11.50$, but cash purchases at electronics stores are six times as high. Unlike grocery stores where checks were used for the largest average transactions, credit and charge cards have the highest averages here at roughly \$150. Cash is the only payment instrument with an overall merchant cost similar to grocery stores. Checks are around three times as costly for electronics stores; signature debit cards are 
over twice as costly. That said, cash is still the cheapest instrument for electronics stores to accept and checks are second.

\begin{tabular}{|c|c|c|c|c|c|c|c|}
\hline & & Cash & Check & $\begin{array}{l}\text { MC/Visa } \\
\text { Credit }\end{array}$ & Discover & $\begin{array}{l}\text { American } \\
\text { Express }\end{array}$ & $\begin{array}{l}\text { Signature } \\
\text { Debit }\end{array}$ \\
\hline \multirow[t]{7}{*}{ Section A } & POS Time & 0.06 & 0.15 & 0.12 & 0.11 & 0.11 & 0.12 \\
\hline & Drawer/Office & 0.05 & 0.03 & 0.06 & 0.06 & 0.06 & 0.06 \\
\hline & Bank Charges & 0.05 & 1.38 & 2.94 & 1.71 & 3.44 & 1.86 \\
\hline & Losses & 0.08 & 0.07 & 0.03 & 0.04 & 0.04 & 0.03 \\
\hline & Float & 0.01 & 0.02 & 0.02 & 0.02 & 0.02 & 0.01 \\
\hline & Other Direct Costs & 0.07 & 0.02 & 0 & 0 & 0 & 0 \\
\hline & Per Transaction Total Cost & 0.32 & 1.67 & 3.16 & 1.95 & 3.67 & 2.08 \\
\hline \multirow[t]{3}{*}{ Section B } & Average Receipt for Payment & & & & & & \\
\hline & Type & 64.98 & 124.66 & 150.39 & 149.87 & 148.15 & 99.3 \\
\hline & Cost Scaled to $\$ 100$ of Sales & 0.49 & 1.34 & 2.10 & 1.30 & 2.48 & 2.09 \\
\hline \multirow[t]{2}{*}{ Section C } & $\begin{array}{l}\text { Cost, Cash Transaction Size } \\
\$ 64.98\end{array}$ & 0.32 & 1.63 & 1.47 & 0.94 & 1.71 & 1.52 \\
\hline & $\begin{array}{l}\text { Cost, Check Transaction Size } \\
\$ 124.66\end{array}$ & 0.39 & 1.67 & 2.65 & 1.65 & 3.12 & 2.47 \\
\hline
\end{tabular}

Table 5: Per transaction processing costs for various payment instruments electronics specialty store merchants (\$)

Notes: Charge and credit cards are combined for American Express. Store cards and other cards (such as Diners Club charge and credit) are omitted here. Numbers may not add due to rounding.

Source:Coopers \& Lybrand (1995) and authors’ calculations.

Table 6 presents social costs (that is, for merchants plus the other three parties) and adds benefits to the calculations.

Electronics specialty stores likely enjoy a benefit that is not applicable to the other case studies. Before general-purpose credit cards, merchants selling relatively high-priced items often provided in-store installment credit plans. Appliances in particular were often bought on a time plan (Olney, 1999; and Caldor, 1999). By accepting credit cards, electronics specialty stores do not have to shoulder the expense of providing in-store credit. We do not include the marginal elements of this benefit (cost savings) in our calculations, as we do not have a reasonable means of estimating it. If included, it would lower the cost of credit cards relative to cash.

Despite the differences in many of the individual cost and benefit elements, Table 6 presents a relative ranking based on net social marginal costs that is fairly similar to the other case study. Cash is again among the most costly payment method for society, at either transaction size. One surprising result is the relative standing of checks. Unlike grocery store transactions, here checks emerge as cheaper than cash and debit cards. The result is driven by the high bank charge assessed merchants for checks as compared to the processing cost, charges that are netted out in the net social marginal cost calculations. It is unlikely that commercial banks are truly profiting more from checks used at electronics stores. Rather, it is likely that banks charge a higher fee to electronics stores because the 
higher purchase amounts imply greater fraud and non-sufficient fund risks for banks, the costs of which are not captured in our average processing cost estimates.

\begin{tabular}{|c|c|c|c|c|c|c|}
\hline & Cash & Check & $\begin{array}{l}\text { MC/Visa } \\
\text { Credit }\end{array}$ & Discover & $\begin{array}{l}\text { American } \\
\text { Express }\end{array}$ & $\begin{array}{l}\text { Signature } \\
\text { Debit }\end{array}$ \\
\hline \multicolumn{7}{|l|}{ Consumers } \\
\hline Float & 0,0 & $.01, .02$ & $.05, .10$ & $.05, .10$ & $.05, .10$ & 0,0 \\
\hline Credit Option & 0,0 & 0,0 & $.18, .34$ & $.18, .34$ & $.18, .34$ & 0,0 \\
\hline Record Keeping & 0,0 & $.04, .04$ & $.04, .04$ & $.04, .04$ & $.04, .04$ & $.04, .04$ \\
\hline Cash Back option & 0,0 & 0,0 & 0,0 & 0,0 & 0,0 & 0,0 \\
\hline Signature Debit & 0,0 & 0,0 & 0,0 & 0,0 & 0,0 & $.13, .13$ \\
\hline Reward Cards & 0,0 & 0,0 & $.62,1.18$ & $.33, .62$ & $.62,1.18$ & 0,0 \\
\hline Privacy & $.65,1.25$ & 0,0 & 0,0 & 0,0 & 0,0 & 0,0 \\
\hline Consumer Marginal Benefits & $.65,1.25$ & $.04, .05$ & $.88,1.66$ & $.59,1.10$ & $.88,1.66$ & $.17, .18$ \\
\hline \multicolumn{7}{|l|}{ Central Bank } \\
\hline Processing Revenue & $.002, .002$ & $.03, .03$ & 0,0 & 0,0 & 0,0 & 0,0 \\
\hline Seigniorage & $.39, .75$ & 0,0 & 0,0 & 0,0 & 0,0 & 0,0 \\
\hline Central Bank Marginal Benefits & $.39, .75$ & $.03, .30$ & 0,0 & 0,0 & 0,0 & 0,0 \\
\hline \multicolumn{7}{|l|}{ Commercial Banks } \\
\hline Float & 0,0 & 0,0 & 0,0 & 0,0 & 0,0 & $.01, .02$ \\
\hline Processing Revenue & $.08, .08$ & $1.38,1.38$ & $1.27,2.43$ & $.74,1.43$ & $1.51,2.89$ & $1.31,2.26$ \\
\hline $\begin{array}{l}\text { Commercial Bank Marginal } \\
\text { Benefit }\end{array}$ & $.08, .08$ & $1.38,1.38$ & $1.27,2.43$ & $.74,1.43$ & $1.51,2.89$ & $1.32,2.28$ \\
\hline Sum of Marginal Benefits & $1.12,2.08$ & $1.45,1.46$ & $2.15,4.09$ & $1.33,2.53$ & $2.39,4.55$ & $1.48,2.44$ \\
\hline Social Marginal Costs & $2.10,2.99$ & $.67, .71$ & $1.44,1.91$ & $1.49,1.99$ & $1.44,1.91$ & $1.09,1.22$ \\
\hline Sum of Marginal Costs & $2.18,3.07$ & $2.07,2.12$ & $2.73,4.34$ & $2.25,3.43$ & $2.97,4.81$ & $2.40,3.48$ \\
\hline Net Social Marginal Costs & $1.06, .99$ & .62,.66 & $.56, .25$ & $.90, .90$ & $.56, .26$ & $.92,1.04$ \\
\hline
\end{tabular}

Table 6: Adding selected benefits, electronics specialty store cash $(\$ 64.98)$ and check (\$124.66) transactions (\$)

Notes: The first and second numbers in each cell correspond to the lower and higher transaction sizes, respectively. Numbers may not add due to rounding. Net Social Marginal Cost equals the Sum of Marginal Costs minus the Sum of Marginal Benefits, which eliminates transfers across the parties (such as merchant payments to commercial banks for check processing). Social Marginal Costs are included for reference.

Source:Authors' calculations. 


\section{$5 \quad$ Distributional effects}

The overall social welfare question is the focus of our analysis in this paper - whether the data support the proposition that one additional electronic payment transaction costs society more than one additional paper payment transaction. As the tables and discussions above indicate, we do not find any evidence that electronic payment methods cost society more.

Our data let us examine a related question as well - whether one additional electronic payment transaction affects the different parties in different ways. Table 7 below reorders the data from the first case study to address that question. Parties bearing relatively more of the costs for a given instrument are likely to push for regulatory changes - as was the case in the Australian Reserve Bank investigation of payment card systems, where retailer complaints spurred regulators.

\begin{tabular}{|c|c|c|c|c|c|c|}
\hline & Cash & $\begin{array}{c}\text { Non- } \\
\text { Verified } \\
\text { Check }\end{array}$ & $\begin{array}{l}\text { Verified } \\
\text { Check }\end{array}$ & Credit & $\begin{array}{l}\text { Signature } \\
\text { Debit }\end{array}$ & PIN Debit \\
\hline Merchant Marginal Costs & $.30, .43$ & $.41, .63$ & $.44, .47$ & $.61,1.22$ & $.68, .82$ & $.57, .57$ \\
\hline Merchant Marginal Benefits & 0,0 & 0,0 & 0,0 & 0,0 & 0,0 & 0,0 \\
\hline Net Merchant MC & $.30, .43$ & $.41, .63$ & $.44, .47$ & $.61,1.22$ & $.68, .82$ & $.57, .57$ \\
\hline Consumer Marginal Costs & $.65,1.27$ & $.70, .70$ & $.65, .65$ & $.46, .46$ & $.46, .46$ & $.55, .55$ \\
\hline Consumer Marginal Benefits & $.12, .54$ & $.19, .19$ & $.19, .19$ & $.18, .60$ & $.16, .16$ & $.16, .16$ \\
\hline Net Consumer MC & $.53, .73$ & $.52, .51$ & $.46, .46$ & $.28,-.14$ & $.30, .30$ & $.39, .39$ \\
\hline Central Bank Marginal Costs & $0, .01$ & $.03, .03$ & $.03, .03$ & 0,0 & 0,0 & 0,0 \\
\hline Central Bank Marginal Benefits & $.07, .33$ & $.03, .03$ & $.03, .03$ & 0,0 & 0,0 & 0,0 \\
\hline Net Central Bank MC & $-.07,-.32$ & 0,0 & 0,0 & 0,0 & 0,0 & 0,0 \\
\hline Comm. Bank Marginal Costs & $.07, .31$ & $.12, .12$ & $.12, .12$ & $.34, .65$ & $.27, .35$ & $.27, .35$ \\
\hline Comm. Bank Marginal Benefits & $.03, .04$ & $.06, .06$ & $.16, .16$ & $.42,1.01$ & $.50, .64$ & $.54, .54$ \\
\hline Net Comm. Bank MC & $.03, .27$ & $.06, .06$ & $-.04,-.04$ & $-.09,-.36$ & $-.23,-.29$ & $-.26,-.19$ \\
\hline
\end{tabular}

Table 7. The distribution of private costs and benefits, grocery store transactions (\$)

Notes: The first and second numbers in each cell correspond to the lower and higher transaction sizes, respectively. Numbers may not add due to rounding.

Source: Authors' calculations.

The table confirms what we already knew: merchants face relatively high net private costs for electronic payment methods as compared to paper payments. The costs are driven by bank charges. Of course, merchant benefits are not truly zero for each payment method. With better data on the benefits of accepting credit cards and avoiding in-house credit departments, for instance, the cost ranking would likely change. 
Consumers, on the other hand, face far higher net private costs for cash and checks as compared to cards. In fact, consumers receive net benefits from using credit to pay for larger transactions. Consumer private costs are almost entirely time-based for all instruments, including such items as the time cost of obtaining cash at an ATM and the time cost of processing a payment at the point of sale, both of which favor electronic payment methods. Consumer private benefits are driven by cash back for checks at the grocery store, which enables consumers to avoid going to an ATM for smaller cash purchases. For credit cards, rewards are by far the largest item, although the option value of credit is non-trivial for larger purchases.

Commercial banks, like consumers, receive net benefits from payment cards. In spite of the fact that processing costs for payment cards are the largest cost item that banks face, since the revenues are larger banks receive net gains. Banks' net costs for paper instruments are quite small--the exception is cash for larger purchases, where the cost is driven by the expense of maintaining ATM machines.

\section{Conclusion}

Consumers are gradually moving away from paper payment instruments and toward electronic ones, especially payment cards. The implications of the shift toward a cashless society are hotly debated. The courts in the United States and regulators in Australia and Europe have already made substantial policy interventions in the markets for various payment instruments. We believe that this debate needs to be better informed by both economic theory and empirical research.

As a step in that direction, we clarify cost and benefit accounting for payment instruments from both a private and a social perspective. The existing empirical literature is not adequate for this task for many reasons, chief among them because it typically disregards benefits and does not always consider all parties to a transaction. We argue that both social costs and social benefits need to be considered when comparing payment instruments for policy decisions.

While the calculations presented here do not cover all costs and benefits, our analysis represents a substantial improvement over the existing literature. Conceptually, our calculations are fairly straightforward. In practice, the individual cost and benefit components are quite difficult to estimate but are crucial for understanding payment instrument use. We construct two case studies that focus on the shift away from paper instruments and toward payment cards. The case studies present three key findings:

- $\quad$ First, transaction size assumptions are critical in analyzing payment-processing costs. At smaller transaction sizes, the net social marginal cost of all payment instruments - paper and electronic alike - are remarkably similar. No one instrument stands out as more socially efficient. At larger transaction sizes, however, significant differences emerge. For grocery store transactions, electronic payments are considerably less costly on net for society than paper methods. Yet another pattern emerges for the larger transactions conducted at electronics stores. Here credit cards with a large proportion of reward cardholders have the lowest net social marginal cost. This pattern is consistent with observed behavior: namely that cash use dominates smaller transaction sizes but drops precipitously as transaction size increases. 
- $\quad$ Second, retailer type influences the individual cost elements and thus affects private cost calculations. Since the distribution of transaction sizes differs across venues, this result follows naturally from our first finding. Added to the transaction size effect are apparent differences in merchant costs, such as point of sale time and back office processing costs.

- $\quad$ Finally, and most importantly, the relative merits of different payment methods change significantly when all parties are counted and benefits are included. Merchant studies have found that paper methods are the cheapest for merchants. This is confirmed in our study of the distribution of private costs and benefits. But what is cheap for merchants is relatively expensive for other parties to a transaction. Certain parties, especially consumers, receive considerable benefits from payment cards, which tip their net private costs in favor of that method of payment.

Unfortunately, the case studies also highlight the difficulty of quantifying benefits. For instance, while we were able to identify a number of potential benefits for merchants, we were unable to quantify any of them. As such, our net social marginal costs should not be interpreted as definitive numbers, but rather as illustrative.

We find that when all key parties to a transaction are considered and benefits are added, cash and checks are not as desirable as many earlier studies suggest. In general, the shift toward a cashless society appears to improve economic welfare.

The fact that the shift away from cash and checks is probably economically beneficial does not imply that all parties have benefited. Our analysis suggests that certain groups, notably consumers, are likely to gain from this shift. In contrast, some merchants may not benefit. The distributional implications of the shift away from paper instruments need to be examined more carefully.

\section{$7 \quad$ References}

Baxter, W. (1983) "Bank Interchange of Transactional Paper: Legal and Economic Perspectives,” Journal of Law and Economics, 26: 541-588.

Brito, Dagobert L. and Peter R. Hartley (1995) "Consumer Rationality and Credit Cards," Journal of Political Economy, 103: 400-433.

Calder, Lendol (1999) Financing the American Dream: A Cultural History of Consumer Credit. Princeton University Press: Princeton, NJ.

Carow, Kenneth A. and Michael E. Staten (1999) "Debit, Credit, or Cash: Survey Evidence on Gasoline Purchases,” Journal of Economics and Business 1999; 51:409-421.

Castronova, Edward and Paul Hagstrom (2004) "The Demand for Credit Cards: Evidence from the Survey of Consumer Finances,” Economic Inquiry, 42: 304-18.

Chakravorti, Sujit (2002) "Theory of Credit Card Networks: A Survey of the Literature," Review of Network Economics, 2: 50-68. 
Coopers \& Lybrand (1995). "Survey of Retail Merchants to Determine Costs of Payment Acceptance,” Prepared for Visa USA.

Evans, David S. (2003) “The Antitrust Economics of Multi-Sided Platform Markets,” Yale Journal on Regulation, 20: 325-381.

Evans, David S. and Richard Schmalensee (2005) Paying with Plastic: The Digital Revolution in Buying and Borrowing. MIT Press: Cambridge, MA. Forthcoming.

Food Marketing Institute (1998) A Retailer's Guide to Electronic Payment Systems Costs. Food Marketing Institute: Washington, D.C.

Garcia-Swartz, Daniel D., Robert W. Hahn, and Anne Layne-Farrar (2006) "The Move Toward a Cashless Society: Calculating the Costs and Benefits," Review of Network Economics, 5:175-198.

Goulder, Lawrence H. and Roberton C. Williams III (2003) “The Substantial Bias from Ignoring General Equilibrium Effects in Estimating Excess Burden, and a Practical Solution,” Journal of Political Economy, 111: 898-927.

Humphrey, David B., Göran Bergendahl, Ted Lindblom, and Magnus Willesson (2003) "What Does It Cost to Make a Payment?" Review of Network Economics, June 2003, 2: 159-174.

Humphrey, David B. and Allen N. Berger (1990) "Market Failure and Resource Use: Economic Incentives to Use Different Payment Instruments,” in David B. Humphrey (ed.), The U.S. Payment System: Efficiency, Risk and the Role of the Federal Reserve. Kluwer Academic Publishers: Boston, MA.

Humphrey, David B., Lawrence B.Pulley, and Jukka M. Vesala (1996) "Cash, Paper, and Electronic Payments: A Cross-Country Analysis,” Journal of Money, Credit and Banking, 28: 914-939.

Klee, Elizabeth (2004) "Paper or Plastic: The Effect of Time on Check and Debit Card Use at Grocery Stores,” SSRN Working Paper, http://ssrn.com/abstract=687159

Lacker, Jeffrey M. (1993) “Should We Subsidize the Use of Currency?” Federal Reserve Bank of Richmond Economic Quarterly, 79: 47-73.

MacKie-Mason, Jeffrey K. and Kimberly White (1996) "Evaluating and Selecting Digital Payment Mechanisms," Working paper, University of Michigan, presented at Telecommunications Policy Research Conference, October 5-7, 1996.

Mantel, Brian (2000) "Why Don’t Consumers Use Electronic Banking Products? Toward a Theory of Obstacles, Incentives, and Opportunities,” Federal Reserve Bank of Chicago Emerging Payments Occasional Paper Series EPS-2000-1, September. 
Neumann, Manfred J.M. (1992) "Seigniorage in the United States: How Much Does the U.S. Government Make from Money Production?” The Federal Reserve Bank of St. Louis Review, 74: 29-40.

Nocera, Joseph (1994) A Piece of the Action: How the Middle Class Joined the Money Class. Simon \& Schuster: New York.

Olney, Martha L. (1999) "Avoiding Default: The Role of Credit in the Consumption Collapse of 1930,” Quarterly Journal of Economics, 114: 319-335.

Parker, Geoffrey G. and Marshall W. Van Alstyne (2000) "Information Complements, Substitutes and Strategic Product Design," Available at SSRN: http://ssrn.com/abstract=249585.

Rochet, Jean-Charles (2003) "The Theory of Interchange Fees: A Synthesis of Recent Contributions,” Review of Network Economics, 2: 97-124.

Rochet, Jean-Charles and Jean Tirole (2002) "Cooperation Among Competitors: Some Economics of Payment Card Associations,” Rand Journal of Economics, 33: 549-570.

Rochet, Jean-Charles and Jean Tirole (2003) "Platform Competition in Two-Sided Markets,” Journal of European Economic Association, 1: 990-1029.

Santomero, Anthony M. and John J. Seater (1996) "Alternative Monies and the Demand for Media of Exchange,” Journal of Money, Credit, and Banking, 28: 942-960.

Schmalensee, Richard (2002) "Payment Systems and Interchange Fees," Journal of Industrial Economics, 50: 103-22.

Slesnick, Daniel T. (1998) "Empirical Approaches to the Measurement of Welfare," Journal of Economic Literature, 36: 2108-2165.

Stavins, Joanna (1997) “A Comparison of Social Costs and Benefits of Paper Check Presentment and ECP Truncation,” New England Economic Review, July/August: 27-44.

Stavins, Joanna (2001) "Effect of Consumer Characteristics on the Use of Payment Instruments,” New England Economic Review, Issue Number 3: 19-31.

Thaler, Richard H. and H. M. Shefrin (1981) “An Economic Theory of Self-Control,” Journal of Political Economy, 89: 392-406.

Wells, Kirstin E. (1996) “Are Checks Overused?” Federal Reserve Bank of Minneapolis Quarterly Review, 2: 2-12.

Whitesell, William C. (1989) “The Demand for Currency versus Debitable Accounts," Journal of Money, Credit, and Banking, 21: 246-251. 